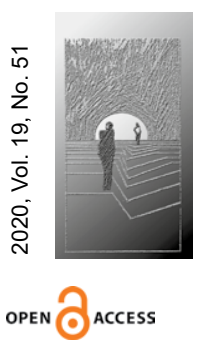

\title{
Gabriela Wronowska
}

http://orcid.org/0000-0001-9519-3690 Uniwersytet Ekonomiczny w Krakowie Kolegium Ekonomii, Finansów i Prawa Instytut Ekonomii wronowsg@uek.krakow.pl DOI: $10.35765 / h w .1876$

\section{Edukacja dla przedsiębiorczości na przykładzie wybranych działań Uniwersytetu Ekonomicznego w Krakowie}

\section{STRESZCZENIE}

CEL NAUKOWY: Celem artykułu jest prezentacja wybranych działań Uniwersytetu Ekonomicznego w Krakowie realizowanych w ramach edukacji dla przedsiębiorczości jako odpowiedź na dynamicznie zmieniające się otoczenie społeczno-gospodarcze.

METODY I NARZĘDZIA BADAWCZE: W realizacji celu pracy pomogły: studia literaturowe, opracowania statystyczne, analiza dokumentów, wyniki uzyskane w badaniach ankietowych.

PROCES WYWODU: Prezentowane treści zostały podzielone na tematyczne części. Pierwsza, teoretyczna, pokazuje tło analizowanego zagadnienia oraz wybrane aspekty edukacji dla przedsiębiorczości. W drugiej zostały przedstawione wybrane przykłady edukacji dla przedsiębiorczości realizowane przez Uniwersytet Ekonomiczny w Krakowie.

WYNIKI ANALIZY NAUKOWEJ: Wskazane działania, tj. dualny kierunek studiów, różnorodne szkolenia i staże dla studentów oraz wsparcie oferowane dla uczniów, są odpowiedzią na oczekiwania współczesnego rynku pracy. Uniwersytet Ekonomiczny w Krakowie, wychodząc naprzeciw wyzwaniom otoczenia gospodarczego, kreując rozwiązania na podstawie swojego potencjału i zewnętrznego wsparcia finansowego, staje się uniwersytetem przedsiębiorczym.

WNIOSKI, INNOWACJE, REKOMENDACJE: W pracy zaprezentowano podejście do edukacji dla przedsiębiorczości w kontekście zmian demograficznych. Skutki tego zjawiska powodują konieczność zmiany nie tylko polityki rynku pracy, ale również wymuszają wypracowanie skutecznych metod pozyskiwania młodych pracowników. Warto podkreślić, jak ważna obecnie staje się rola przedsiębiorczych uniwersytetów w procesie kształcenia młodych ludzi, którzy mają sprostać oczekiwaniom pracodawców oraz dynamicznie zmieniającemu się otoczeniu gospodarczemu.

$\rightarrow$ SŁOWA KLUCZOWE: EDUKACJA DLA PRZEDSIĘBIORCZOŚCI, STUDIA WYŻSZE, DEMOGRAFIA, PRZEDSIĘBIORCZOŚCI 


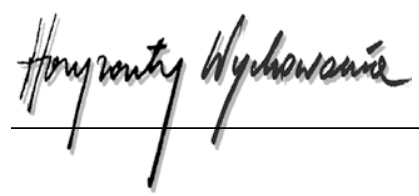

ABSTRACT

Education for Entrepreneurship on the Example of Selected Activities of the Cracow University of Economics

RESEARCH OBJECTIVE: The aim of the article is to present selected activities of the Cracow University of Economics carried out within the framework of education for entrepreneurship as a response to the dynamically changing socio-economic environment.

THE RESEARCH PROBLEM AND METHODS: Literature studies, statistical studies, document analysis, survey results helped to achieve the aim of the work.

THE PROCESS OF ARGUMENTATION: The presented content is divided into thematic parts. The first theoretical part presents the background of the analysed issue and selected aspects of education for entrepreneurship. The second part contains presentation of selected examples of education for entrepreneurship implemented by the Cracow University of Economics.

RESEARCH RESULTS: The answer to the expectations of the contemporary labour market are the indicated activities, i.e. a dual course of study, various trainings and internships for students and support offered to students. The Cracow University of Economics is becoming an entrepreneurial university meeting the challenges of the economic environment and creating solutions based on its potential and external financial support.

CONCLUSIONS, INNOVATIONS, AND RECCOMENDATIONS: The paper presents an approach to education for entrepreneurship in the context of demographic change. The effects of this phenomenon on the labour market make it necessary not only to change the labour market policy, but also to develop effective methods of attracting young employees. It is worth emphasising that the important role of entrepreneurial universities is growing at the moment when it comes to the process of educating young people, who are to meet the expectations of employers and the dynamically changing economic environment.

$\rightarrow$ KEYWORDS: ENTREPRENEURSHIP EDUCATION, HIGHER EDUCATION, DEMOGRAPHY, ENTREPRENEURSHIP

\section{Wstęp}

Celem pracy jest omówienie wybranych działań podejmowanych przez Uniwersytet Ekonomiczny w Krakowie, które mają na celu m.in. budowanie postaw przedsiębiorczych wśród młodych ludzi, odpowiadając tym samym na potrzeby rynku pracy. Działania te to: szkolenia dla studentów, programy edukacyjne dla młodzieży szkół podstawowych i średnich oraz nowe kierunki studiów łączące teorię z praktyką. Punktem wyjścia dla rozważań podjętych w pracy jest pytanie: dlaczego kształtowanie postaw przedsiębiorczych wśród młodych ludzi, przyszłych uczestników rynku pracy, jest obecnie istotne z punktu widzenia zarówno rozwoju zasobów ludzkich, jak i przyszłego rozwoju oraz 
kondycji gospodarki? Odpowiedź jest złożona i wiąże się m.in. ze zmianami społecznymi w kontekście starzejącego się społeczeństwa i wyzwań, jakie w związku z tym procesem stoją przed rynkiem pracy i systemem kształcenia. W pracy zaproponowano spojrzenie na edukację przedsiębiorczą w odniesieniu do zmian demograficznych. Jej rola zyskuje na znaczeniu, gdyż młodzi ludzie wchodzący na rynek pracy powinni praktycznie wykorzystywać wiedzę z zakresu przedsiębiorczości.

\section{Metody badawcze}

Aby zrealizować cel pracy i udzielić odpowiedzi na postawiony w pracy problem badawczy, wybrano następujące metody badawcze: studia literaturowe, dane statystyczne i prognozy opracowane przez GUS, analizę wniosków i dokumentów prawnych, uwzględniono częściowe wyniki uzyskane w badaniach ankietowych z wykorzystaniem ankiety online oraz ankiety audytoryjnej przeprowadzanej wśród wybranej grupy studentów na Uniwersytecie Ekonomicznym w Krakowie.

\section{Postawy przedsiębiorcze a starzejące się społeczeństwo}

Sytuacja demograficzna w krajach Unii Europejskiej, w tym również w Polsce, charakteryzuje się trendami, które skłaniają do zmiany podejścia w projektowaniu i prowadzeniu polityki rynku pracy (Sipurzyńska-Rudnicka, 2018). Procesy demograficzne wpływają zwłaszcza na podażową stronę rynku pracy. W tym ujęciu najważniejsze są te związane z kształtowaniem wielkości, struktury wiekowej oraz poziomu wykształcenia (kapitału ludzkiego) przyszłego zasobu pracy. Na podstawie opracowania GUS (2017) można przytoczyć prognozowane do 2030 r. dane świadczące o kierunkach zmian demograficznych w Polsce. Współczynnik dzietności rośnie i jego szacowana wielkość w 2030 r. to 1,55 . Poziom ten jest jednak za niski, aby mógł gwarantować zastępowalność pokoleń, która występuje dopiero od poziomu 2,10 i pozwala sprawnie funkcjonować rynkowi pracy oraz systemowi zabezpieczeń społecznych. Rośnie również wskaźnik oczekiwanej długości życia w momencie narodzin, zarówno dla mężczyzn, jak i dla kobiet. Prognozowane poziomy wynoszą odpowiednio: 78,1 i 84,6 lat. Od lat obserwowany jest niepokojący trend, który prowadzi do starzenia się większości społeczeństw europejskich. Proces ten ma następujące konsekwencje dla rynku pracy:

a) systematyczne zmniejszenie się zasobów pracy; zgodnie z obliczeniami Sipurzyńskiej-Rudnickiej (2018) ubytek ten będzie wynosił 1,5 mln osób na każdą dekadę, do 2040 r.;

b) zmiana struktury zasobów pracy;

c) zwiększenie udziału osób starszych w zasobach pracy;

d) wzrost wskaźnika obciążenia demograficznego;

e) zagrożenie niewydolnością systemów emerytalnych;

f) dynamiczny rozwój srebrnej gospodarki. 


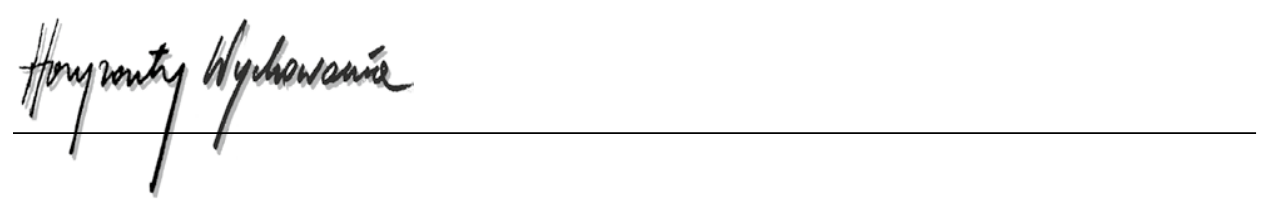

Ponadto proces ten wymusza zmiany na rynku pracy w następujących obszarach:

a) zmiany polityki zatrudnienia w stosunku do osób 50+;

b) wypracowanie szybkiej ścieżki (tranzycji) pozyskiwania młodych pracowników;

c) konieczność powstania grupy usługodawców, którzy będą nastawieni na zaspokojenie potrzeb starzejącego się społeczeństwa.

Obok problemów wynikających ze starzejącej się populacji ważna jest sytuacja ludzi młodych wchodzących na rynek pracy. Liczba osób młodych podejmujących zatrudnienie co roku zmniejsza się, a sam proces przechodzenia z systemu edukacji na rynek pracy, zwany tranzycją, przebiega w wieloraki sposób. W ślad za Piróg (2013) można wskazać co najmniej kilka jej rodzajów. Najbardziej niepokojący jest jednak fakt, że młodzi ludzie odchodzą od modelu wejścia w dorosłe życie, który składał się z trzech elementów realizowanych jednocześnie w krótkim okresie, tuż po zakończeniu edukacji. Elementy te to podjęcie pracy zawodowej, usamodzielnienie się poprzez założenie własnego gospodarstwa domowego oraz założenie rodziny. Dominującym modelem staje się tranzycja prolongowana, która polega na świadomym i celowym przedłużaniu przez studentów okresu kształcenia, który opóźnia moment wejścia na rynek pracy, oraz odkładanie na przyszłość momentu założenia rodziny i posiadania dzieci. Na podstawie badań ankietowych, przeprowadzonych wśród studentów kierunku Analityki Ekonomiczno-Finansowej na Uniwersytecie Ekonomicznym w Krakowie w roku akademickim 2019/2020 dotyczących sposobów tranzycji, można stwierdzić, że wśród badanej grupy dominuje tranzycja opóźniona ze względu na masowe kontynuowanie kształcenia na poziomie wyższym, a w jej ramach typ tranzycji rozmytej, gdyż ponad $50 \%$ badanych łączy studia z pracą. Tego rodzaju tranzycji może doświadczać coraz więcej absolwentów szkół wyższych w Polsce ze względu na wybór priorytetów życiowych oraz projektowanie ścieżki kariery ${ }^{1}$. Biorąc pod uwagę motywy, którymi kierują się młodzi ludzie, dokonując wyborów związanych z kształceniem i pracą, można wskazać chęci zdobywania wiedzy, nowych umiejętności i kwalifikacji, ale również obawę przed dorosłym życiem, brak pewności siebie oraz pomysłu na siebie. Świadczy to o deficytach, z którymi absolwenci opuszczają system kształceni. Te niedostatki, które mogą być efektem zaniedbań edukacyjnych w obszarze kształtowania postawy przedsiębiorczej i budowania kompetencji miękkich, są wyzwaniem dla uczelni wyższych, które z definicji (uniwersytetu przedsiębiorczego) kładą nacisk na użyteczność wiedzy (Gwizdała i Śledzik, 2018).

\section{Edukacja na rzecz budowania postawy przedsiębiorczej}

Zmniejszający się zasób podaży pracy dodatkowo obciążony tranzycją opóźnioną powoduje, że młodzi ludzie nie angażują się na rynku pracy w sposób pełny i efektywny. Wydaje się, że przynajmniej częściowo można zmniejszyć skalę tranzycji opóźnionej,

${ }^{1}$ Wyniki badań autorka zawarła w pracy pt. Rynek pracy w Polsce z perspektywy studentów szkół wyższych. Wybrane zagadnienia - praca w druku. 
eliminując przyczyny jej powstania mające swe źródła w niedostatkach edukacji przedsiębiorczej. Na podstawie istniejącego w literaturze przedmiotu konsensusu (Henry, Hill i Leitch, 2005), że „przynajmniej niektórych aspektów przedsiębiorczości można nauczać z powodzeniem" (Wach, 2016), to od zaangażowania i skali podejmowanych wysiłków zależy poziom edukacji przedsiębiorczej uczelni.

Za Urbaniec (2014) można podać, że celem systemu edukacyjnego, realizowanego na wszystkich poziomach kształcenia, powinno być kształtowanie postaw przedsiębiorczych wśród młodzieży i studentów, co pozwoli im na efektywne i zadowalające uczestnictwo zarówno na rynku pracy, jak i w życiu prywatnym. Edukacja na rzecz przedsiębiorczości funkcjonuje w środowisku uniwersyteckim na świecie od lat 80. XX w. Kształcenie w zakresie przedsiębiorczości zostało zapoczątkowane w Stanach Zjednoczonych. Obecnie edukacja na rzecz przedsiębiorczości jest wprowadzona na stałe do standardowych programów kształcenia na poziomie wyższym² (Wach, 2013), a jest to uwarunkowane jej rolą w procesie rozwoju społeczno-gospodarczego na wielu płaszczyznach (Jankiewicz, 2006; Zioło i Rachwał, 2007; Gołębiewski, 2008; Gierańczyk, 2009; Zioło i Rachwał, 2009). W literaturze przedmiotu istnieje wiele definicji oraz podejść do pojęcia edukacja przedsiębiorcza. Najbardziej popularne podejście do przedsiębiorczości związane jest z zakładaniem i prowadzeniem własnej działalności gospodarczej, a edukacja w tym przypadku ma na celu kształtować umiejętności potrzebne przyszłym przedsiębiorcom. W szerszym znaczeniu edukacja przedsiębiorcza wychodzi poza ramy działalności gospodarczej i rozciąga proces kształcenia jednostki również w kontekście rozwiązywania problemów życia codziennego (Andrzejczyk, 2016). Na potrzeby niniejszego opracowania punktem wyjścia do rozważań stało się podejście do edukacji przedsiębiorczej w ślad za K. Wachem (2016). Według tego autora edukację przedsiębiorczą można odnieść do następujących obszarów:

a) rozwój zasobów ludzkich, który jest rozumiany jako bardziej przedsiębiorczy pracownicy z umiejętnościami potrzebnymi na rynku pracy;

b) rozwój kultury przedsiębiorczej;

c) rozwój społeczeństwa obywatelskiego, które przejawia większe zaangażowanie w życie społeczne, wykorzystując działania przedsiębiorcze;

d) stymulowanie nowych start-upów;

e) rozwój działalności biznesowej;

f) stymulowanie umiędzynarodowienia poprzez osoby przedsiębiorcze.

Zgodnie z przyjętym podejściem edukację przedsiębiorczą traktuje się jako kształtowanie postaw i umiejętności oraz przekazywanie wiedzy z zakresu przedsiębiorczości w celu rozwoju zasobów ludzkich i ich przedsiębiorczych działań zarówno na rynku pracy, jak i w życiu codziennym. Osoby przedsiębiorcze charakteryzują się określonym zbiorem cech, wśród których są: zdolność do przewidywania, skłonność do podejmowania ryzyka,

2 Badania nad przedsiębiorczością prowadzone są od ponad 20 lat przez Global Entrepreneurship Monitor (GEM). Na ich podstawie można stwierdzić, że poziom przedsiębiorczości wśród ludzi młodych jest niezadowalający (https://www.gemconsortium.org/report). 


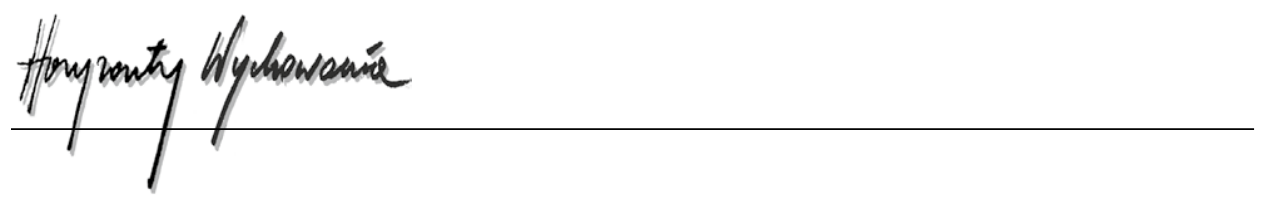

dostosowanie się do zdarzeń zachodzących w gospodarce, dostrzeganie i wykorzystywanie okazji, poszukiwanie skutecznych sposobów realizacji działań, to styl bycia, sposób postrzegania świata, myślenia i działania (Andrzejczyk, 2016, s. 12). Niektórzy ludzie nie posiadają tych cech, lecz nie oznacza to, że nie mogą zostać osobami przedsiębiorczymi. Edukacja przedsiębiorcza jest takim działaniem, które może pożądane cechy wypracować na drodze edukacji formalnej, czyli w placówkach edukacyjnych, tj. szkołach i uczelniach wyższych. Cechy te można budować również podczas edukacji nieformalnej odbywającej się poza systemem kształcenia i w procesie uczenia przez całe życie (lifelong learning).

Faktem staje się proces przemiany uczelni wyższych w uniwersytety przedsiębiorcze. Uniwersytet, stając się uniwersytetem przedsiębiorczym, charakteryzuje się pięcioma cechami (Clark, 1998); są to: wzmocnienie centrum sterującego, rozszerzenie powiazań z otoczeniem, zróżnicowanie źródeł finansowania, stymulowanie centrum akademickiego, ożywienie kultury przedsiębiorczości. Podobne cechy wskazuje Leja (2013, s. 57); są to: zmiana charakteru relacji uniwersytetów z otoczeniem, poszukiwanie nowych źródeł finansowania i lepsze wykorzystanie środków publicznych. Można wskazać, że szanse na stanie się uniwersytetem przedsiębiorczym mają placówki młode, powstające i funkcjonujące w mniejszych ośrodkach kształcenia, które budują swoją strukturę od podstaw. Mogą one przyciągnąć studentów, dobrych wykładowców i nauczycieli oraz fundusze, które w dużym stopniu wspierają działania przedsiębiorcze. Współczesny rynek pracy ma jasno określone oczekiwania względem uczelni wyższych. Mają to być instytucje kształcące pracowników, którzy posiadają szeroki wachlarz cech, w tym zwłaszcza te związane z przedsiębiorczością i umiejętnościami miękkimi (Andrzejczyk, 2015). Nie każda uczelnia wyższa wywiązuje się z tej narzuconej roli. W przypadku uczelni z bogatymi tradycjami typowo humboldtowskiego uniwersytetu, proces przekształcania w kierunku instytucji o charakterze przedsiębiorczym z wielu powodów jest trudny, długotrwały, a czasami w danym momencie niemożliwy. Bierność w działaniu wynika z wielu lat takiej praktyki postępowania. Dotyczy to zwłaszcza starszej kadry naukowej. Z kolei młodzi pracownicy chcący wnieść nowe idee i działania napotykają ze strony starszych doświadczonych kolegów niechęć, zdziwienie i brak zrozumienia. Dodatkową barierą jest sam sposób funkcjonowania uczelni wyższych wynikający ze ściśle określonych mechanizmów postępowania, procedur i utartych zasad. Z tych m.in. powodów tradycyjnie funkcjonujące uniwersytety nie są instytucjami wspierającymi rynek w takim wymiarze, w jakim się tego od nich oczekuje.

Uniwersytet Ekonomiczny w Krakowie to uczelnia z długą tradycją ${ }^{3}$, jednak nie zamyka się ona na nowe wyzwania płynące z otoczenia gospodarczego. Realizuje działania o charakterze edukacji dla przedsiębiorczości odbywające się zarówno w ramach programu studiów, jak i poza nim. Ciekawym projektem dydaktycznym została objęta również młodzież z wybranych szkół średnich i podstawowych.

${ }^{3}$ Uniwersytet Ekonomiczny w Krakowie został założony 25 maja 1925 r. Szkoła wyższa otrzymała nazwę Wyższego Studium Handlowego (WSH). 


\section{Przykłady edukacji dla przedsiębiorczości na Uniwersytecie Ekonomicznym w Krakowie}

Część działań o charakterze przedsiębiorczym na uczelniach wyższych w Polsce regulowana jest przepisami ustawy Prawo o szkolnictwie wyższym i nauce (2018). Uczelnie zgodnie $z$ art. 148 wspomnianej ustawy mogą prowadzić akademickie inkubatory przedsiębiorczości oraz centra transferu technologii. Mają również możliwość zgodnie z art. 62, 63 i 64 ustawy prowadzić kształcenie w trybie studiów dualnych.

W 2018 r. Uniwersytet Ekonomiczny w Krakowie, prowadząc swoją działalność edukacyjną, rozszerzył ofertę dydaktyczną o projekty finansowane ze źródeł zewnętrznych. Korzystając z tej możliwości finansowania działań dydaktycznych, które uczelnia realizuje, opierając się na istniejącej kadrze dydaktycznej i posiadanym zapleczu, złożyła ona dwa odrębne wnioski do Narodowego Centrum Badań i Rozwoju i podjęła starania o sfinansowanie dwóch projektów, które takie finansowanie otrzymały ${ }^{4}$. Od 2019 r. ruszyła ich realizacja i są one przykładem edukacji dla przedsiębiorczości. Poniżej zostaną scharakteryzowane.

\section{Zintegrowany Program Rozwoju UEK}

Projekt Zintegrowany Program Rozwoju UEK (ZPR UEK) 5 jest ogólnouczelnianym, szeroko zakrojonym projektem realizowanym w ramach Programu Operacyjnego Wiedza Edukacja Rozwój 2014-2020. Projekt ten został sfinansowany z środków Europejskiego Funduszu Społecznego ${ }^{6}$ i ma objąć swoim wsparciem 1480 studentów studiów stacjonarnych i niestacjonarnych oraz 386 pracowników uczelni ${ }^{7}$. Studenci, do których skierowane jest wsparcie w ramach tego projektu, w postaci trzech grup zadań ${ }^{8}$, to osoby charakteryzujące się niewystarczającym przygotowaniem do wejścia na rynek pracy. Mają wystarczającą wiedzę, ale nie potrafią wykorzystać jej w praktyczny sposób. Posiadają luki kompetencyjne w obszarach: komunikacji, pracy w zespole, analizy danych i wyciągania wniosków, przedsiębiorczości, negocjacji, wyszukiwania informacji i ich weryfikacji. Motywacją do działania jest perspektywa lepszego startu na rynku pracy i zdobycie atrakcyjnego zatrudnienia. Celem projektu jest podniesie kompetencji uczestników, które odpowiadają potrzebom rynku pracy. Założeniem projektu jest wyposażenie w kompetencje

${ }^{4}$ Do realizacji celu pracy zostały wybrane te dwa projekty.

${ }^{5}$ Zintegrowany Program Rozwoju UEK, nr wniosku: POWR.03.05.00-00-Z217/18.

${ }^{6}$ Kwota dofinansowania ze środków europejskich: 19144 912,10 zł. Całkowita wartość projektu to 19739 057,74 zł.

${ }^{7}$ Charakterystyka omawianego projektu będzie dotyczyła tylko wsparcia dla studentów.

${ }^{8}$ Wszystkich zadań w projekcie jest 6 , z czego 3 dedykowane są studentom i absolwentom szkół średnich. 


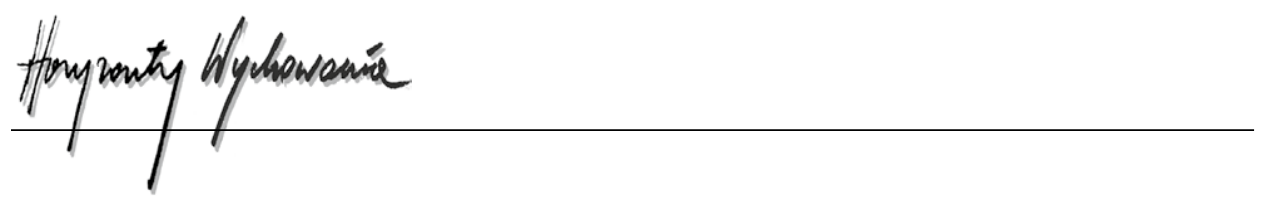

ułatwiające wejście na rynek pracy przez udział w certyfikowanych szkoleniach, zajęciach warsztatowych kształcących kompetencje zawodowe, zajęcia projektowe oraz wizyty studyjne i zajęcia z pracodawcami. Oczekiwane efekty wsparcia dla studentów dotyczą wzrostu kompetencji zawodowych, językowych, komunikacyjnych, a zwłaszcza w zakresie przedsiębiorczości.

Zadanie pierwsze realizowane w projekcie ZPR UEK to wprowadzenie nowych lub modyfikacja istniejących programów kształcenia. Innowacyjne działanie w ramach tego zadania to uruchomienie po raz pierwszy w roku akademickim 2019/2020 nowego kierunku Doradztwo Inwestycyjno-Gospodarcze, który będzie realizowany w trybie studiów dualnych. Praktyczny profil kształcenia jest lepszym sposobem na zdobywanie wiedzy i budowanie postawy przedsiębiorczej przyszłych uczestników rynku pracy. Kierunek ten został uruchomiony na podstawie art. 62 Ustawy (Prawo, 2018) i dedykowany w pierwszym roku 60 studentom na pierwszym stopniu kształcenia ${ }^{9}$. Unowocześniając ofertę kształcenia na uczelni, utworzono nowe specjalności. Są to: Doradztwo Biznesowe i Global Business Services. W ramach specjalności Doradztwo Biznesowe większy nacisk będzie położony na umiejętności praktyczne związane z podejmowaniem decyzji gospodarczych. W odróżnieniu od obecnie dostępnych specjalność ta będzie realizowana głównie w formie zajęć laboratoryjnych z wykorzystaniem komputerowych programów statystycznych i symulacyjnych.

Twórcy anglojęzycznej specjalności pozyskali do współpracy 18 firm z Global Business Services, które zadeklarowały chęć zatrudnienia jej absolwentów. Istotą tej specjalizacji jest przygotowanie studentów do pracy i podejmowania dalszego kształcenia w rozwijającym się obszarze shared service ${ }^{10}$. Dotychczasowe programy kształcenia zostaną sukcesywnie zmodyfikowane przez wprowadzenie nowych metod i narzędzi, takich jak: eksperyment społeczny, gry edukacyjne czy też Indywidualną Ścieżkę Edukacyjną ${ }^{11}$.

Zadanie drugie w ramach projektu ZPR UEK to program szkoleń i warsztatów dostosowany do indywidualnych potrzeb studentów. Jest on odpowiedzią na potrzeby zgłaszane przez pracodawców (Ciepucha, 2019). Oferta zawiera 34 szkoleń, w tym: 5 tzw. innowacyjnych warsztatów, 7 szkoleń z obszaru IT, 8 szkoleń z kompetencji miękkich, 11 szkoleń zawodowych oraz 3 wizyty studyjne. Tematyka szkoleń jest mocno zróżnicowana i koncentruje się wokół obszarów wymagających wsparcia ${ }^{12}$.

Zdanie trzecie związane jest z programami stażowymi oferowanymi przez przedsiębiorstwa działające w Polsce. Ten rodzaj wsparcia dla studentów ma wymiar czysto

\footnotetext{
${ }_{9}^{9}$ Opis zaczerpnięto z Wniosku o dofinansowanie projektu Program Operacyjny Wiedza Edukacja Rozwój, POWR.03.05.00-IP.08-00-PZ2/18 s. 35.

10 Tamże, s. 328.

11 Tamże, s. 18.

12 Szczegółowy opis tematyki szkoleń dostępny na https://power.uek.krakow.pl/\#top (dostęp: 13.02.2020).
} 
praktyczny. Pozwala studentom na aktywny udział w rynku pracy i zdobycie pierwszych zawodowych doświadczeń.

Po raz pierwszy na Uniwersytecie Ekonomicznym w Krakowie realizowany jest projekt oferujący studentom tak duże wsparcie w ramach edukacji formalnej dla budowania kompetencji, zdobywania nowych umiejętności oraz wiedzy praktycznej.

\section{Młodzieżowy Uniwersytet Ekonomiczny}

Projekt Młodzieżowy Uniwersytet Ekonomiczny (MUE) ${ }^{13}$ realizowany jest w ramach Programu Operacyjnego Wiedza Edukacja Rozwój 2014-2020. Jest on współfinansowany ze środków Europejskiego Funduszu Społecznego ${ }^{14}$. Celem projektu MUE jest podniesienie wiedzy, umiejętności i kompetencji społecznych młodzieży szkół podstawowych i średnich w wybranych powiatach Małopolski. Projekt obejmuje sześć powiatów z wysoką stopą bezrobocia wśród młodych (25\%). Zakładanym skutkiem realizacji oferowanych szkoleń ma być zmniejszenie luki kompetencyjnej, poprawa mobilności zawodowej młodzieży oraz poprawa komunikacji interpersonalnej. Wsparcie dla uczniów w ramach projektu MUE to 35 szkoleń prowadzonych w formie tradycyjnej i e-learningowej w obszarach: komunikacyjnym, osobistym i zawodowym. Projekt MUE jest skierowany do uczniów klas szóstych szkół podstawowych i uczniów klas pierwszych szkół średnich, którzy oczekują podniesienia kompetencji miękkich, społecznych, cyfrowych i w zakresie wiedzy specjalistycznej. Projekt zakłada realizację szkoleń w trzech edycjach. Programy szkoleń są dostosowane do poziomu uczestników i będą realizowane z wykorzystaniem nowoczesnych narzędzi, np. gier planszowych i decyzyjnych, symulacji komputerowych, filmów edukacyjnych, pracy z fantomami, metody PBL oraz case study ${ }^{15}$. Innowacyjność tego projektu polega na kierowaniu wsparcia przez uczelnię wyższą do uczniów znajdujących się na niższych poziomach kształcenia. Pozwala on nawiązać współpracę z innymi placówkami edukacyjnymi oraz wyjść z ofertą dydaktyczną poza mury uczelni. Projekt ten oferuje innowacyjny, kompleksowy program szkoleń uczniom w obszarach istotnych z punktu widzenia wyboru dalszej ścieżki kształcenia i - w dalszej perspektywie - wejścia na rynek pracy.

Można stwierdzić, że realizacja tego typu projektów obecnie i w przyszłości stawia Uniwersytet Ekonomiczny w Krakowie w roli uniwersytetu przedsiębiorczego.

\footnotetext{
${ }^{13}$ MUE, nr projektu: POWR.03.01.00-00-T220/18.

${ }^{14}$ Kwota dofinansowania ze środków europejskich: 2505 178,95 zł. Całkowita wartość projektu to 2972447,73 zł.

${ }^{15}$ Informacje zaczerpnięte z Wniosku o dofinansowanie projektu Program Operacyjny Wiedza Edukacja Rozwój, nr POWR.03.01.00-IP.08-00-3MU/1, s. 6-7.
} 


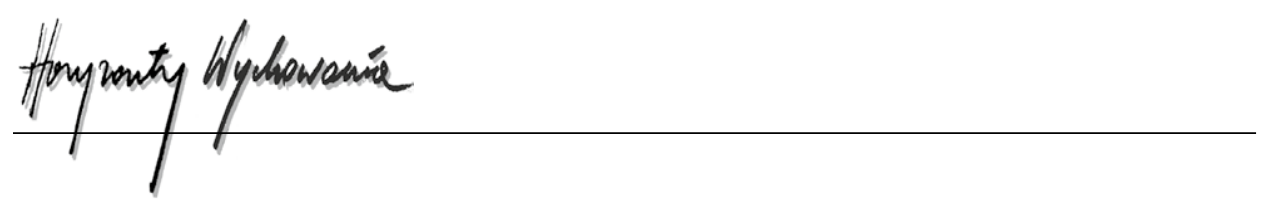

\section{Wyniki analizy naukowej}

Przytoczone w opracowaniu działania podejmowane przez Uniwersytet Ekonomiczny w Krakowie można traktować jako edukację dla przedsiębiorczości zgodnie z podejściem przyjętym w pracy. Wskazane działania, tj. dualny kierunek studiów, zróżnicowane szkolenia i staże dla studentów oraz wsparcie oferowane dla uczniów szkół średnich i podstawowych, są odpowiedzią na oczekiwania współczesnego rynku pracy. Realizacja projektów trwa, natomiast ocena ich na wielu płaszczyznach będzie możliwa dopiero w przyszości. Istnieje jednak poważna obawa, że obecna sytuacja wywołana pandemią może znacząco wpłynąć na tę ocenę.

Uniwersytet Ekonomiczny w Krakowie, wychodząc naprzeciw wyzwaniom otoczenia gospodarczego, kreując rozwiązania na podstawie swojego potencjału i zewnętrznego wsparcia finansowego, staje się uniwersytetem przedsiębiorczym.

\section{Wnioski}

W pracy postawiono pytanie: dlaczego kształtowanie postaw przedsiębiorczych wśród młodych ludzi, przyszłych uczestników rynku pracy, jest obecnie tak istotne z punktu widzenia zarówno rozwoju zasobów ludzkich, jak i przyszłego rozwoju oraz kondycji gospodarki? Szukając odpowiedzi na to pytanie, zaprezentowano podejście do edukacji dla przedsiębiorczości w kontekście zmian demograficznych skutkujących starzeniem się społeczeństwa. Nieodwracalne skutki tego zjawiska, zwłaszcza na rynku pracy, powodują konieczność zmiany nie tylko polityki rynku pracy, ale również wymuszają wypracowanie skutecznych metod pozyskiwania odpowiednio wykwalifikowanych młodych pracowników. Ważne jest również skrócenie procesu tranzycji na rynek pracy absolwentów uczelni wyższych poprzez ograniczenie barier, które ten proces wydłużają, przyczyniając się do deprecjacji kapitału ludzkiego i strat powstających z tego tytułu w skali mikroi makroekonomicznej. Warto podkreślić, jak ważna obecnie jest rola uczelni wyższych, przedsiębiorczych uniwersytetów w procesie kształcenia młodych ludzi wchodzących na rynek pracy, którzy mają sprostać oczekiwaniom pracodawców oraz ciągle zmieniającemu się otoczeniu gospodarczemu.

\section{BibLIOGRAFIA}

Andrzejczyk, A. (2015). Uniwersytet przedsiębiorczy i odpowiedzialny społecznie. Edukacja Ekonomistów i Menedżerów: problemy innowacje projekty, 4(38), 117-130.

Andrzejczyk, A. (2016). Wpływ edukacji na rozwój przedsiębiorczości. Raport z badań. PTE odział w Białymstoku. DOI: 10.24136/eep.mon.2016.4

Ciepucha, E. (2019). Zapotrzebowanie pracodawców na kompetencje społeczne i zawodowe pracowników oraz branże rozwojowe w świetle wyników prac analityczno-badawczych 
Obserwatorium Rynku Pracy dla Edukacji. Łódź: Wydawnictwo i Pracownia Poligraficzna Łódzkiego Centrum Doskonalenia Nauczycieli i Kształcenia Praktycznego.

Clark, B.R. (1998). Creating Entrepreneurial Universities: Organizational Pathways of Transformation. Issues in Higher Education. Oxford: IAU Press.

Dziennik Ustaw Rzeczypospolitej Polskiej (2018). Ustawa z dnia 30 sierpnia 2018 r. Poz. 1668, Prawo o szkolnictwie wyższym i nauce. Warszawa.

Gierańczyk, W. (2009). Rozwój społeczeństwa informacyjnego a przedsiębiorczość w krajach transformujących się. Przedsiębiorczość - Edukacja, 5, 19-36. https://doi.org/10.24917/427

Gołębiewski, G. (2008). Przedsiębiorczość a czynniki społeczno-kulturowe. Problemy Zarządzania, 2(20), 27-38.

Główny Urząd Statystyczny (2017). Prognoza ludności gmin na lata 2017-2030. Pozyskano z: https:// stat.gov.pl/obszary-tematyczne/ludnosc/prognoza-ludnosci/prognoza-ludnosci-gmin-na-lata-2017-2030-opracowanie-eksperymentalne,10,1.html (stan na 12.02.2020).

Gwizdała, J. i Śledzik, K. (2018). Uniwersytet przedsiębiorczy czy uniwersytet społecznie odpowiedzialny? Ocena uniwersyteckiej działalności wdrożeniowej. Prace Naukowe Uniwersytetu Ekonomicznego we Wrocławiu, 531(532), 143-154. DOI: 10.15611/pn.2018.532.14

Henry, C., Hill, F. i Leitch, C. (2005), Entrepreneurship education and training: can entrepreneurship be taught? Part I. Education and Training, 47(2), 98-111.

Jankiewicz, S. (2006). Znaczenie przedsiębiorczości dla rozwoju społeczno-gospodarczego w społecznej nauce Kościoła. Polityka Gospodarcza, 14, 103-112.

Leja, K. (2013). Zarządzanie uczelnią. Koncepcje i współczesne wyzwania. Warszawa: Wolters Kluwer.

Piróg, D. (2013). Wybrane teorie przechodzenia absolwentów szkół wyższych na rynek pracy w warunkach gospodarki opartej na wiedzy. Prace Komisji Geografii Przemysłu Polskiego Towarzystwa Geograficznego, 23, 146-158.

Sipurzyńska-Rudnicka, K. (2018). Przyszłość demograficzna Polski a rynek pracy. Wrocławskie Studia Politologiczne, 24, 104-118. DOI: 10.19195/1643-0328.24.8.

Urbaniec, M. (2014). Współczesne wyzwania edukacji na rzecz przedsiębiorczości w szkolnictwie wyższym. Horyzonty Wychowania, 13(26), 209-230.

Wach, K. (2013). Edukacja na rzecz przedsiębiorczości wobec współczesnych wyzwań cywilizacyjno-gospodarczych. Przedsiębiorczość - Edukacja, 13(9), 247-257.

Wach, K. (2016). Edukacja w zakresie przedsiębiorczości: potencjał dydaktyczny polskich uniwersytetów. Horyzonty Wychowania, 15(35), 11-27. DOI: 10.17399/HW.2016.153501

Zioło, Z. i Rachwał, T. (2007). Rola przedsiębiorczości w aktywizacji gospodarczej - zarys modelu. Przedsiębiorczość - Edukacja, (3), https://doi.org/10.24917/604

Zioło, Z. i Rachwał, T. (2009). Rola przedsiębiorczości w kształtowaniu społeczeństwa informacyjnego. Przedsiębiorczość - Edukacja, 5, https://doi.org/10.24917/2805.

\section{Copyright and License}

This article is published under the terms of the Creative Commons Attribution - NoDerivs (CC BY- ND 4.0) License http://creativecommons.org/licenses/by-nd/4.0/ 